\title{
PROCJENA PROSTORNE RASPODJELE OBORINA U GIS OKRUŽENJU
}

\author{
ESTIMATING SPATIAL DISTRIBUTION OF \\ RAINFALL IN GIS ENVIRONMENT
}

\section{Tea Francetić*, Doris Šporčić", Bojana Horvat", Nino Krvavica*}

\begin{abstract}
Sažetak
Oborine su izrazito varijabilna komponenta bilance voda, koja ovisi o nizu faktora, kao što su geografski položaj, udaljenost od mora i nadmorska visina, a ključne su u razumijevanju hidroloških procesa nekog područja. Mjerenja oborina provode se na diskretnim lokacijama meteoroloških postaja (osim u slučaju radarskih opažanja oborina) te su saznanja o njihovoj varijabilnosti u prostoru rezultat primjene različitih metoda interpolacije izmjerenih vrijednosti u točki na analiziranom prostoru. U GIS okruženju, oborina može biti prikazana u formi diskretnog ili kontinuiranog polja pa će o tome ovisiti i odabir metode interpolacije. U radu su, na primjeru srednjih godišnjih količina oborina za razdoblje 1961. - 1990. na području Istre, prikazane i uspoređene tri najčešće primjenjivane metode prostorne interpolacije: Thiessenovi poligoni, TIN (Triangular Irregular Network) te VLR (metoda višestruke linearne regresije). Prve dvije metode ne uzimaju u obzir faktore koji utječu na količinu palih oborina, već su procijenjene vrijednosti u funkciji udaljenosti promatrane točke od oborinskih postaja. Za razliku od njih, metoda višestruke linearne regresije omogućuje određivanje vrijednosti oborina u prostoru $u$ ovisnosti o drugim čimbenicima; u ovome slučaju to su geografski položaj, udaljenost od mora te nadmorska visina.
\end{abstract}

Ključne riječi: prostorna varijabilnost oborina, prostorna interpolacija, Thiessenovi poligoni, TIN, višestruka linearna regresija

\section{Abstract}

Rainfall is a highly variable water balance component that depends on numerous

\footnotetext{
* Sveučilište u Rijeci, Građevinski fakultet, Radmile Matejčić 3, 51000 Rijeka E-mail: \{tea.francetic, doris,sporcic.\}@student.uniri.hr; \{bojana.horvat, nino.krvavica\}@gradri. uniri.hr
} 
factors such as geographical location, distance from the sea, and elevation. Rainfall is crucial in understanding the hydrological processes in the given catchment. Rainfall measurements are performed at discrete locations at meteorological stations (except in the case of radar measurements). The knowledge of their spatial and temporal variability is the result of applying different methods of interpolation of measured values inside a given area. In a GIS environment, rainfall can be displayed in the form of a discrete or continuous field. Therefore, the choice of the interpolation method depends on the requirements for the type of the result. In this paper, three widely used methods of spatial interpolation are presented and compared to an example of estimating the average annual rainfall in Istria for the period 1961 - 1990. Namely, the following three interpolation methods are considered: Thiessen polygons, TIN (Triangular Irregular Network), and VLR (multiple linear regression method). The first two methods do not consider the factors that affect the amount of rainfall; they only estimate values as a function of the distance of the observed point from the rainfall gauges. In contrast, the method of multiple linear regression determines the spatial distribution of the rainfall from other factors, in this case, the geographical location, distance from the sea, and elevation.

Key words: spatial variability of rainfall, spatial interpolation, Thiessen polygons, TIN, multiple linear regression

\section{Uvod}

Oborine su meteorološki element izrazito promjenljiv u vremenu i prostoru [1], a na njihovu varijabilnost utječe niz čimbenika (atmosferski, topografski, blizina velikih vodenih površina i sl.). Saznanja o prostornoj varijabilnosti uglavnom se temelje na prostornoj interpolaciji oborina izmjerenih u točki (mjernim postajama) i u tu su svrhu primjenjivane različite metode prostorne interpolacije, više ili manje uspješne u opisivanju prostorne varijabilnosti interpolirane veličine.

Uspješnost prostorne interpolacije uvelike ovisi o gustoći i raspoređenosti oborinskih postaja na analiziranom području. Odabir adekvatnog broja mjerenja, koji bi omogućio što precizniji uvid u prostornu raspodjelu neke veličine, u prvom će redu ovisiti o prostornom obuhvatu promatranog fenomena na analiziranom području. Ako se radi o fenomenu malih razmjera, bit će potreban veći broj točaka, nego u slučaju fenomena velikih razmjera. Ukoliko su mjerne postaje na prevelikoj udaljenosti, odnosno ako je broj mjernih postaja premali, neće biti registrirane eventualne iznenadne promjene u prostornoj raspodjeli te će izostati uvid u prostornu dinamiku fenomena. Općenito, oborinske bi postaje trebale biti ravnomjerno raspoređene u prostoru na način da na svakoj od njih pripada otprilike ista utjecajna površina te je potrebno voditi računa i o visinskom razmještaju, a kako bi se što preciznije obuhvatio i orografski utjecaj 
[2]. Svjetska meteorološka organizacija (WMO) preporučuje prosječnu udaljenost među postajama $25-30 \mathrm{~km}$ na ravnom terenu, a u planinskim područjima preporučeni je razmak pola te udaljenosti [referenca].

\section{Prostorna interpolacija}

Prostorna interpolacija je postupak računanja nove vrijednosti na lokaciji za koju ne postoje izmjereni podaci, a koja se nalazi između dvije ili više lokacija s poznatim, izmjerenim podacima [3]. Njezin iznos ne prelazi interval određen točkama između kojih se računa, a vrijednosti dobivene interpolacijom spadaju u područje mogućeg [4]. U Geografskom Informacijskom Sustavu (GIS), metode prostorne interpolacije predstavljaju transformaciju iz prostorno diskretnih podataka (točke, linije) u kontinuirani (rasterski, poligonski) prikaz vrijednosti promatranog fenomena na cijelom analiziranom prostoru.

Problem prostorne interpolacije može se definirati na sljedeći način [5]:

„Za $N$ vrijednosti promatranog fenomena $z_{j}, j=1,2, \ldots, N$, izmjerenih u diskretnim točkama $r_{j}=\left(x_{j}^{[1]}, x_{j}^{[2]} \ldots, x_{j}^{[\mathrm{d}]}\right), j=1,2, \ldots, N$, unutar zadanog područja $d$-dimenzionalnog prostora treba odrediti $d$-varijantnu funkciju $F(r)$, koja prolazi danim točkama i ispunjava uvjet $F\left(r_{j}\right)=z_{j}, j=1,2, \ldots, N$.

Budući da postoji beskonačan broj funkcija koje ispunjavaju zadani uvjet, potrebno je definirati dodatne uvjete koji definiraju karakteristike različitih interpolacijskih tehnika."

Dodatni uvjeti ovisit će ponajprije o karakteristikama promatranog fenomena, specifičnostima primjene te o raspoloživosti izmjerenih podataka.

GIS je u domeni primjene različitih metoda prostorne interpolacije uvelike napredovao posljednjih desetljeća te je danas na raspolaganju niz metoda integriranih u postojeće GIS alate. U ovom će radu biti analizirane i uspoređene tri metode prostorne interpolacije oborinskih podataka: (i) najjednostavnija metoda Thiessenovih poligona, koja rezultira diskretnim poljem poligona (zonama) unutar kojih je svim točkama pridružena količina oborina s najbliže izmjerene lokacije (postaje); (ii) TIN (Triangular Irregular Network) metoda, koja rezultira kontinuiranom raspodjelom izmjerenih količina oborina u formi niza povezanih trokuta; (iii) metoda višestruke linearne regresija, koja u procjeni u obzir uzima i druge faktore koji utječu na količinu oborina, u ovom slučaju nadmorsku visinu, udaljenost od mora te geografski položaj (geografska širina i dužina).

\subsection{Metoda Thiessenovih poligona}

Metoda Thiessenovih poligona često je korištena metoda $u$ određivanju srednje količine oborine na slivu, a temelji se na definiranju utjecajne površine svake postaje [6] te je posebno prikladna za slivove s 
neujednačenim rasporedom oborinskih postaja. Temelji se na tzv. pristupu najbližeg susjeda (engl. nearest neighbour), odnosno pretpostavci da svaka točka utječe na rezultirajuću interpoliranu površinu samo do određene udaljenosti. Ovom se metodom lokaciji s nepoznatom količinom oborina dodjeljuje vrijednost izmjerena na najbližoj oborinskoj postaji, a utjecajno područje se za svaku oborinsku postaju određuje temeljem Thiessenovih (Voronoiovih) poligona.

Thiessenovi poligoni konstruirani su na način da njihova geometrija obuhvaća sve točke koje su prostorno najbliže pojedinoj mjernoj lokaciji u odnosu na preostale mjerne lokacije [7]. Temeljem tako definiranih poligona može se odrediti srednja vrijednost količine oborine na analiziranom području prema izrazu:

$$
P=\sum_{i=1}^{N} w_{i} \times P_{i}
$$

gdje je:

$w_{i}$ - Thiessenov težinski koeficijent za $i$-tu postaju, a određuje se kao omjer površine Thiessenovog poligona na $i$-toj postaji i ukupne površine istraživanog područja, tj.

$P_{i}$ - izmjerena količina oborina na $i$-toj postaji $(\mathrm{mm})$

$A_{i}$ - površina Thiessenovog poligona za $i$-tu postaju $\left(\mathrm{m}^{2}\right)$

$A$ - ukupna površina istraživanog područja $\left(\mathrm{m}^{2}\right)$

Poligoni su konstruirani na način da se susjedne točke (centroidi) spoje linijom te se na tako iscrtane linije konstruiraju simetrale (slika 1). Sjecišta simetrala čine vrhove Thiessenovih poligona koje su najbliže najmanje trima centroidima susjednih poligona, a stranice Thiessenovih poligona su mjesta točaka jednako udaljenih od najmanje dva centroida susjednih poligona [8] (Slika 2).

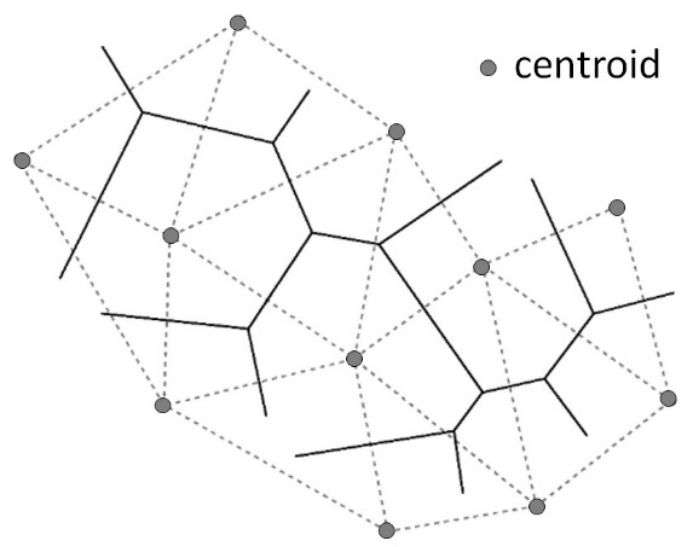

Slika 1. Thiessenovi poligoni 
Nedostatak ove metode je u tome što se vrijednosti fenomena naglo mijenjaju na bridovima poligona pa metoda nije primjenjiva za opis prostorne varijabilnosti većine prirodnih fenomena.

\subsection{TIN metoda}

Riječ je o nepravilnoj mreži trokuta koji ne sadrže pravilan razmak između točaka, a trokuti se međusobno ne preklapaju. Mreža se sastoji iz niza ravnina, koje su dobivene spajanjem susjednih točaka primjenom Delauney triangulacije (Slika 2): trokuti su definirani na način da se konstruira kružnica, koja prolazi kroz vrhove trokuta, a da se istodobno sve druge točke nalaze izvan opisane kružnice tog trokuta [9].

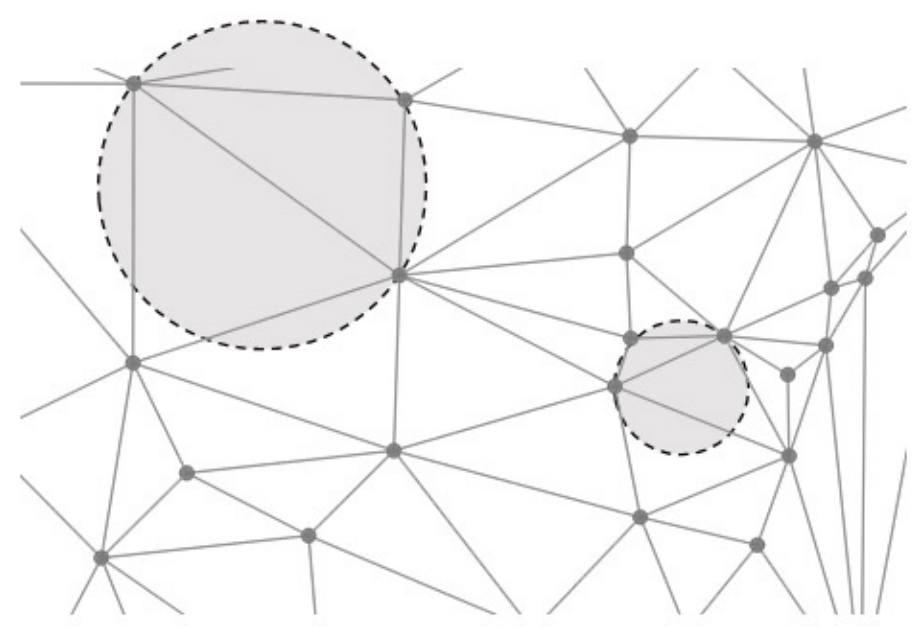

Slika 2. Delauney triangulacija

TIN model je, dakle, sačinjen od niza čvorova i bridova trokuta $\mathrm{s}$ definiranom topologijom. Čvor je točka u kojoj se spajaju bridovi trokuta i definiran je ( $\mathrm{x}, \mathrm{y}, \mathrm{z})$ koordinatama, dok je brid linija, koja spaja čvorove i omeđuju trokute. Nepoznate vrijednosti na lokacijama unutar tako definiranih trokuta procjenjuju se kao kombinacija težinskih udjela vrijednosti izmjerenih u vrhovima trokuta.

Za razliku od prethodno opisane metode Thiessenovih poligona, TIN metoda bolje opisuje prostornu varijabilnost promatranog fenomena, kreirajući kontinuirano polje na kojem se vrijednosti svake lokacije može prikazati kontinuiranom funkcijom. No polje nije glatko i može djelovati zupčasto zbog diskontinuiteta nagiba susjednih trokuta na zajedničkim bridovima. 


\subsection{Višestruka linearna regresija}

Regresijska analiza uključuje mnoge tehnike za modeliranje i analizu varijabli, gdje se fokus stavlja na odnos između zavisne varijable i jedne ili više nezavisnih varijabli. Konkretnije, regresijska analiza pomaže razumjeti kako se mijenja vrijednost zavisne varijable, kada bilo koja nezavisna varijabla varira, dok su ostale nezavisne varijable fiksne. Najčešće, regresijska analiza procjenjuje uvjetno očekivanje zavisne varijable $\mathrm{s}$ obzirom na nezavisne.

Regresijska analiza se često koristi za previđanje i prognoziranje, kao i za razumijevanje odnosa nezavisnih varijabli o zavisnima te istraživanje tih odnosa.

Mnoge primjene regresijske analize uključuju situacije u kojima postoji više od jedne nezavisne ili regresorske varijable [10]. Regresijski model, koji sadrži više od jedne regresorske varijable, naziva se model višestruke regresije. Model višestruke linearne regresije sadrži iste polazne pretpostavke kao i jednostavni model, ali on dodatno ima pretpostavku da nezavisne varijable nisu linearno povezane tj. nisu korelirane. Formula modela osnovnog skupa glasi:

$$
y=\beta_{0}+\sum_{k=1}^{n} \beta_{k} x_{i}
$$

gdje je:

$y$ - zavisna varijabla

$\beta_{0}$-sjecište tj. vrijednost predviđene $y$ varijable kada su sve nezavisne varijable jednake 0

$\beta_{k}$ - koeficijenti linearne regresije

$x_{i}-$ nezavisne varijable

\section{Analizirano područje}

Usporedba rezultata opisanih metoda interpolacije provedena je na području Istre koje se, u pogledu klimatskih karakteristika, odlikuje izrazitom heterogenošću [11]. U priobalnom pojasu karakteristična je sredozemna klima s vrućim i suhim ljetom te prohladnom i vlažnom zimom, dok porastom udaljenosti od obale i porastom nadmorskih visina klima poprima karakteristike umjereno kontinentalne klime pa ljeta postaju topla i vlažna, a zime oštre. Najniži obalni dio, do $150 \mathrm{~m}$ n. m., ima prosječnu siječanjsku temperaturu zraka od $4^{\circ} \mathrm{C}$, a srpanjsku u rasponu $22-24^{\circ} \mathrm{C}$. S porastom nadmorske visine prosječne siječanjske temperature padaju na $2-4^{\circ} \mathrm{C}$, a srpanjske na $20-22^{\circ} \mathrm{C}[12]$. 

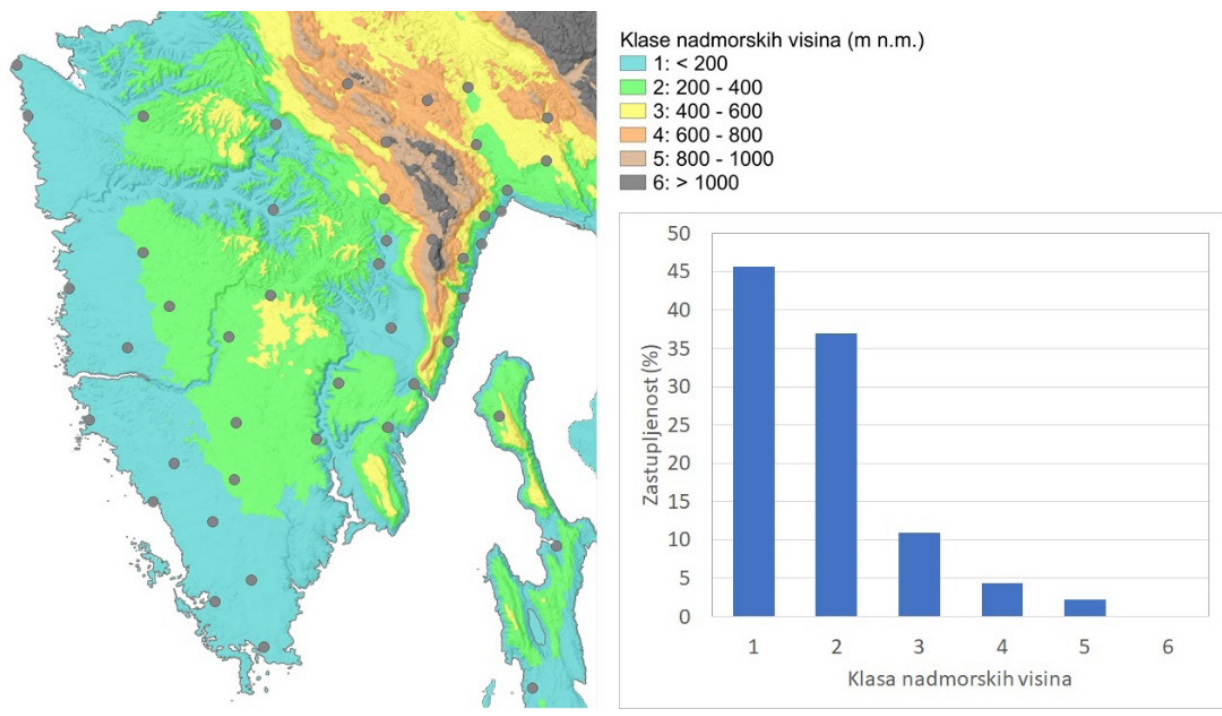

Slika 3. Zastupljenost oborinskih postaja po nadmorskim visinama

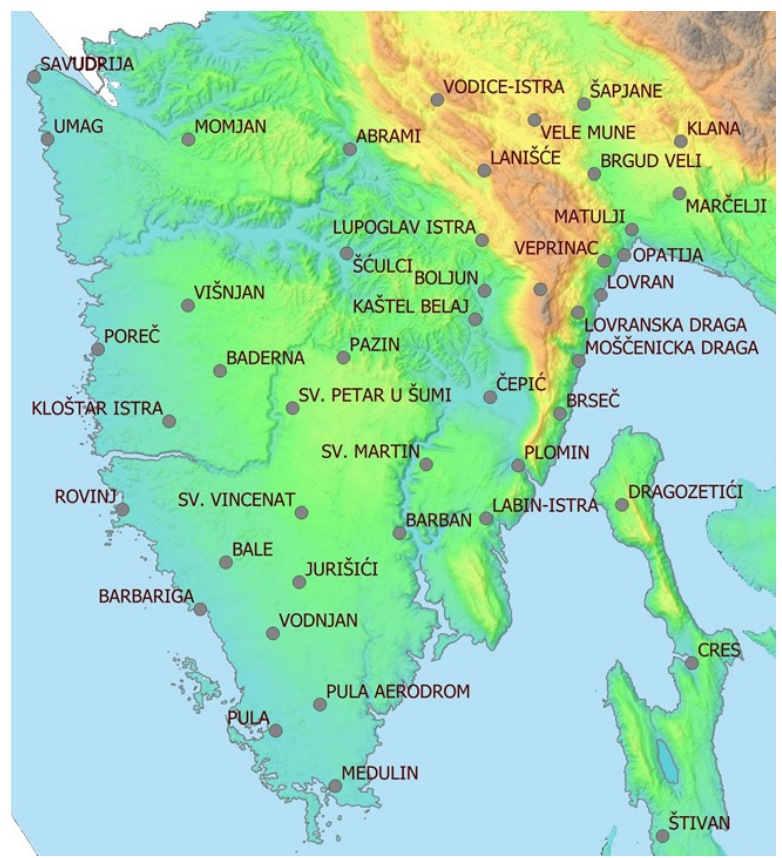

Slika 4. Oborinske postaje na području istarskog poluotoka 
$\mathrm{Na}$ analiziranom području su oborinske postaje raspoređene neravnomjerno (Slika 3): povećavanjem nadmorske visine njihova se zastupljenost smanjuje (najviše ih je u klasi do $199 \mathrm{~m} \mathrm{n}$. m. 50\%, a najmanje iznad $600 \mathrm{~m} \mathrm{n.} \mathrm{m.),} \mathrm{ali} \mathrm{je} \mathrm{gustoća} \mathrm{postaja} \mathrm{najveća} \mathrm{na} \mathrm{sjeveroistočnom} \mathrm{dijelu}$ (Slika 4), gdje su i nadmorske visine najviše. Udaljenosti među postajama uglavnom su i manje od preporuka koje daje Svjetska meteorološka organizacija (WMO): na ravnijem terenu su udaljenosti manje od $25 \mathrm{~km}$, dok su u reljefno razvedenijim područjima udaljenosti i manje od 12,5 km. Od ukupno 46 analiziranih postaja, dvije su glavne meteorološke postaje (obavljaju se motrenja svih meteoroloških elemenata tijekom 24 sata), devet je klimatoloških postaja (motrenja se provode tri puta dnevno), dok je preostalih 35 postaja kišomjernih (obavljaju se samo mjerenja količine oborina jednom dnevno) [13].

Za određivanje prostorne raspodjele oborina korišteni su podaci o količinama oborina izmjerenim na 46 oborinskih postaja (Slika 5) u razdoblju 1961. - 1990. Srednje višegodišnje količine oborina $\left(\mathrm{P}_{\mathrm{SR}}\right)$ za navedeno razdoblje kreću se od $847 \mathrm{~mm}$ (klimatološka postaja Pula) do 2228 mm (kišomjerna postaja Klana) (Slika 5).

\section{Rezultati i diskusija}

Na temelju poznatih koordinata oborinskih postaja kreiran je točkasti podatkovni sloj te je oko svake postaje metodom Thiessenovih poligona izrađen poligon. Rezultat je novi poligonski sloj, koji prikazuje diskretno polje, odnosno prostornu raspodjelu oborina na način da je točkama $u$ prostoru pridružena vrijednost količine oborine izmjerene na najbližoj oborinskoj postaji (Slika 6).

Vrijednosti količine oborina kreću se od minimalnih $847 \mathrm{~mm}$ na jugozapadnom dijelu Istre do $2228 \mathrm{~mm}$ na sjeveroistoku analiziranog područja. Sama površina je diskontinuirana, odnosno podijeljena na nepravilne poligone, a unutar svakog poligona vrijednosti količine oborine identične su vrijednostima izmjerenim na oborinskoj postaji u centroidu tog poligona. Thiessenova metoda se ubraja u tzv. precizne metode prostorne interpolacije, što znači da na lokacijama oborinskih postaja nema odstupanja procijenjenih od izmjerenih vrijednosti.

Točke koje predstavljaju oborinske postaje postupkom triangulacije (Slika 7a) u TIN metodi postaju čvorovi, odnosno vrhovi trokuta u kojima je vrijednost količine oborina jednaka količinama izmjerenim na oborinskim postajama. Potom su kreirani trokuti, koji čine ravnine, a unutar kojih je vrijednost količine oborine dobivena kao rezultat linearne interpolacije izmjerenih vrijednosti količine oborina u vrhovima trokuta (Slika 7b). 


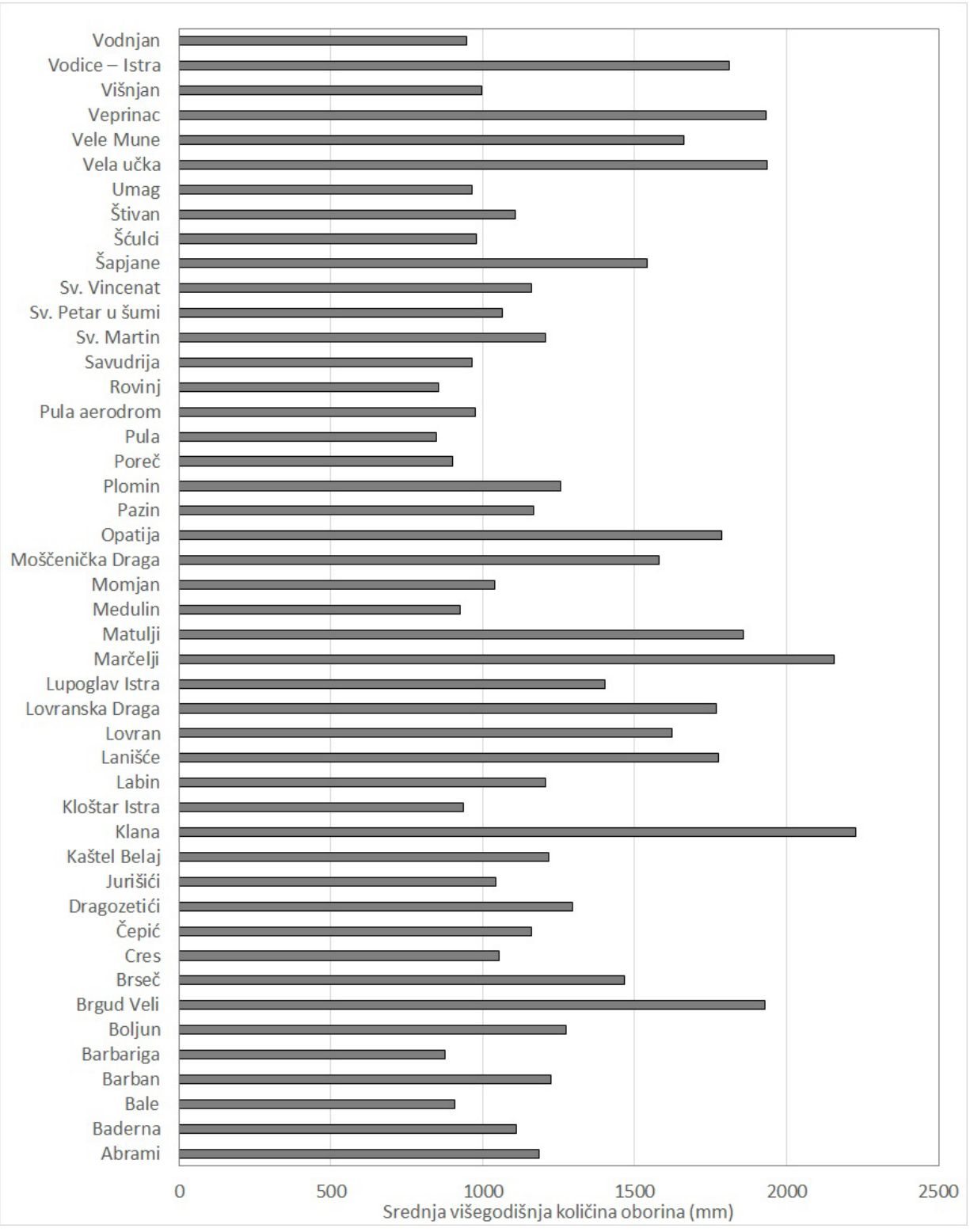

Slika 5. Srednja višegodišnja količina oborina na analiziranim oborinskim postajama 


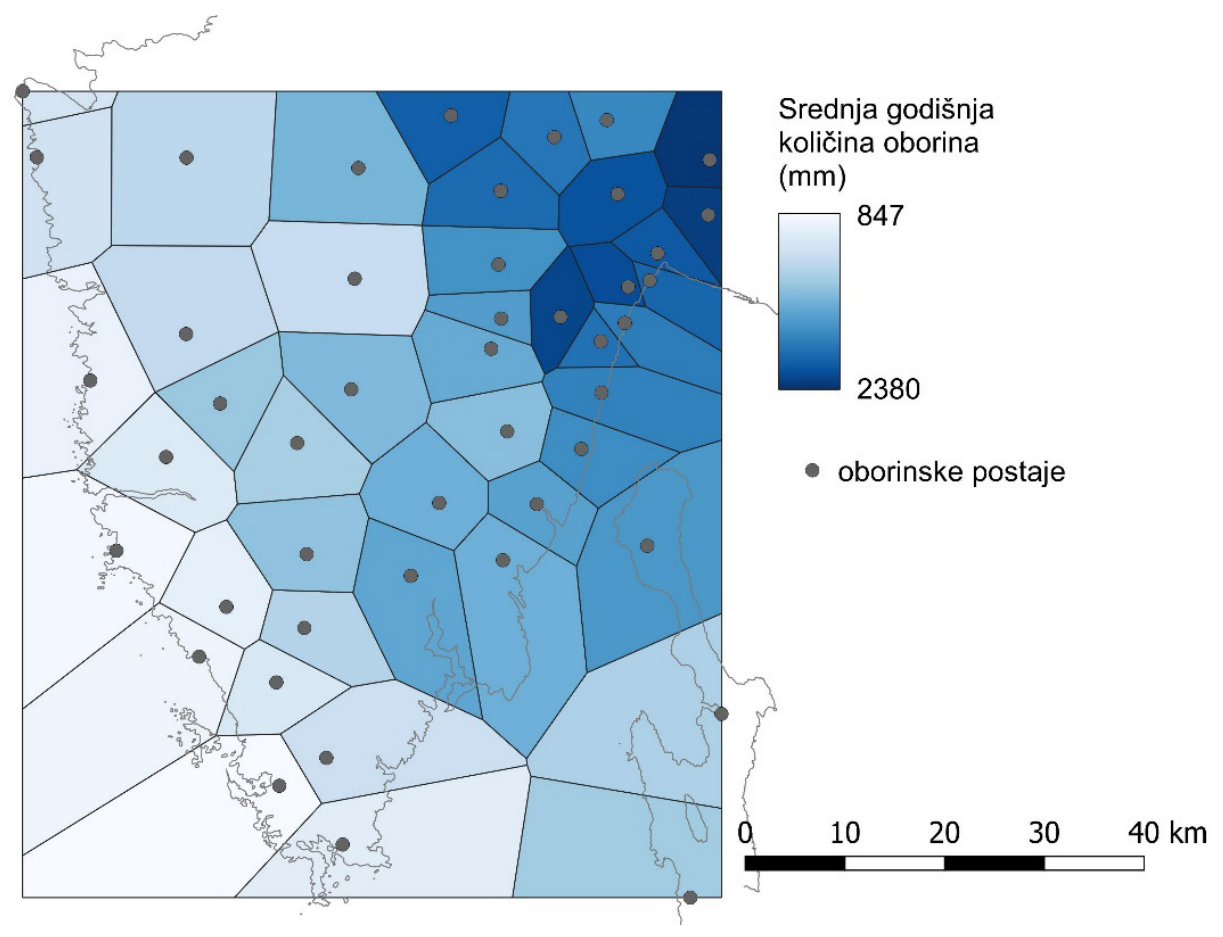

Slika 6. Prostorna interpolacija srednje godišnje količine oborina metodom Thiessenovih poligona 

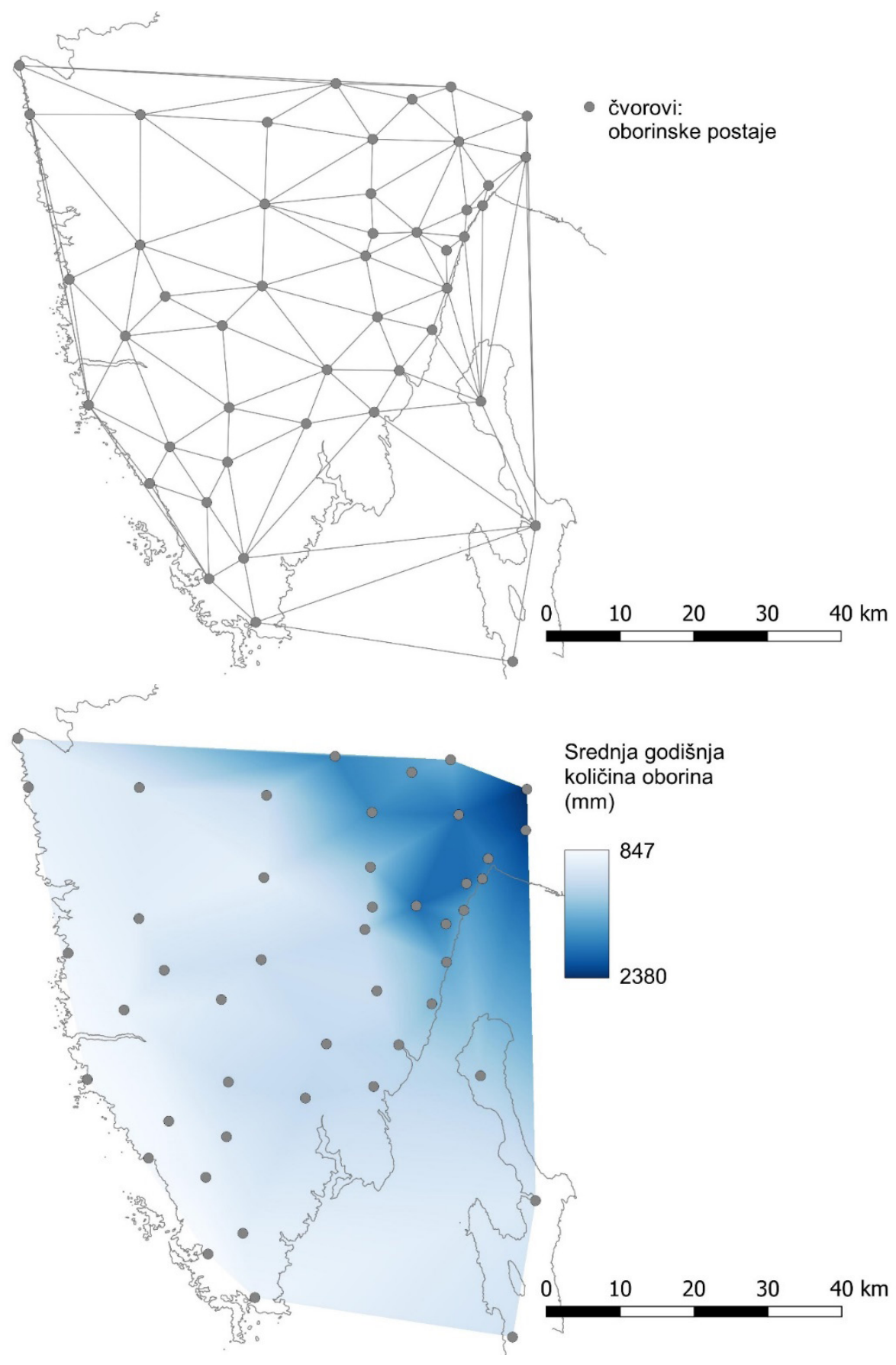

Slika 7. Prostorna interpolacija srednje godišnje količine oborina TIN metodom: a) trokuti TIN površine određeni Delauney triangulacijom; b) procijenjena srednja godišnja količina oborina 
Rezultat primjene ove metode je površina, koja se sastoji od niza nepravilnih trokuta, a koja bolje opisuje prostornu varijabilnost promatranog fenomena, no djeluje izlomljeno na bridovima susjednih trokuta. Također je jasno da će uspješnost primjene ove metode ovisiti i o broju mjernih lokacija ukoliko se radi o vrlo prostorno izrazito varijabilnom fenomenu; mali broj točaka na velikim udaljenostima će rezultirati izglađivanjem te varijabilnosti. Stoga je ova metoda primjenjiva samo lokalno, uz uvjet velikog broja mjernih lokacija usklađenih s varijabilnošću promatranog fenomena. Kao i metoda Thiessenovih poligona, i ova metoda spada u grupu preciznih metoda interpolacije, tj. nema odstupanja procijenjenih od izmjerenih vrijednosti u vrhovima trokuta.

Za razliku od prethodno opisanih metoda interpolacije, metodom višestruke linearne regresije se u procjeni vrijednosti u točkama prostora u kojima nema izmjerenih podataka u obzir uzimaju i faktori koji utječu na količine oborina na toj lokaciji: u ovom slučaju se radi o nadmorskoj visini, udaljenosti od mora i geografskom položaju promatrane lokacije. Za prezentaciju nadmorske visine korišten je digitalni model terena prostorne rezolucije 25 m (EU-DEM, v 1.1) [14] (Slika 8), dok je udaljenost od mora izračunata na temelju vektorizirane obalne linije (Slika 9).

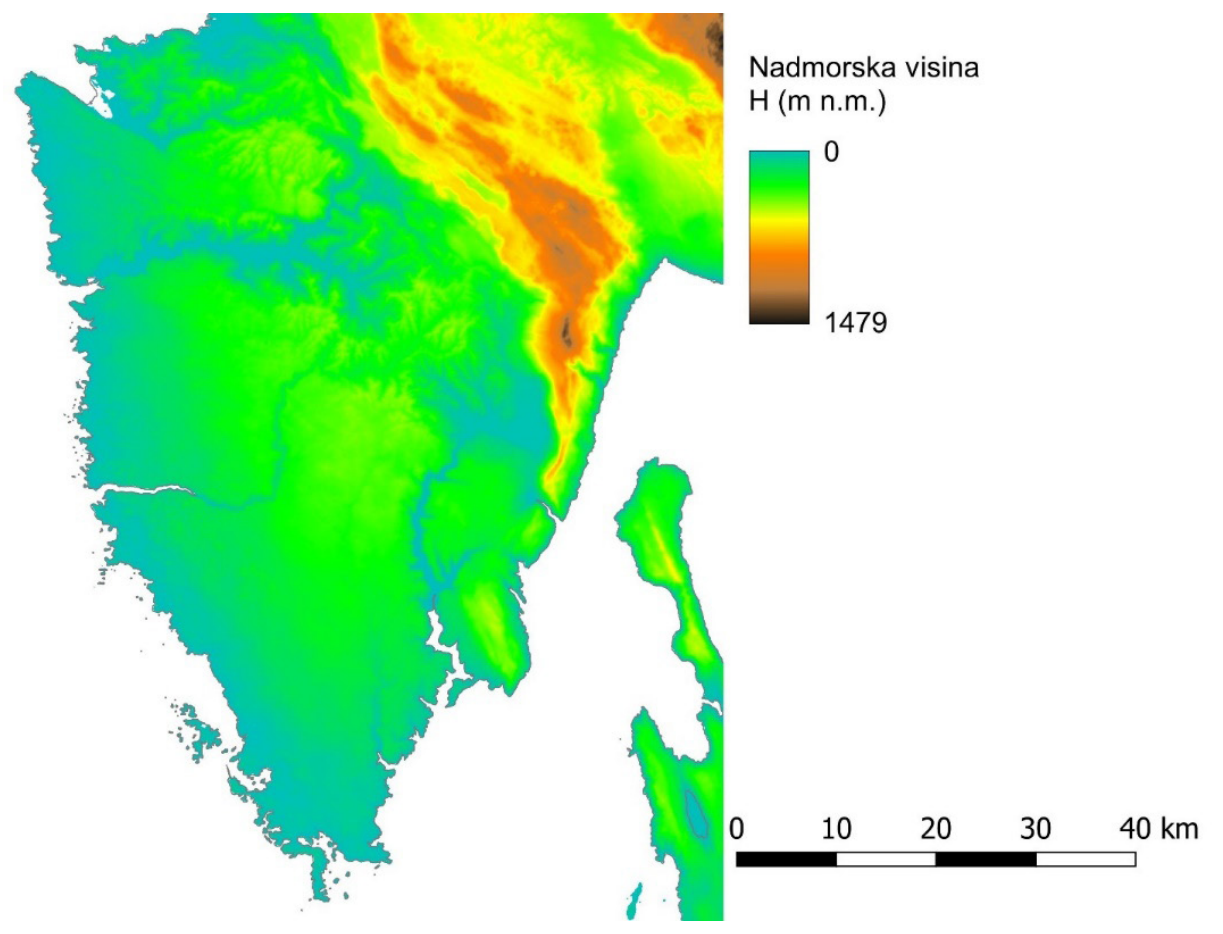

Slika 8. EU-DEM analiziranog područja [14] 


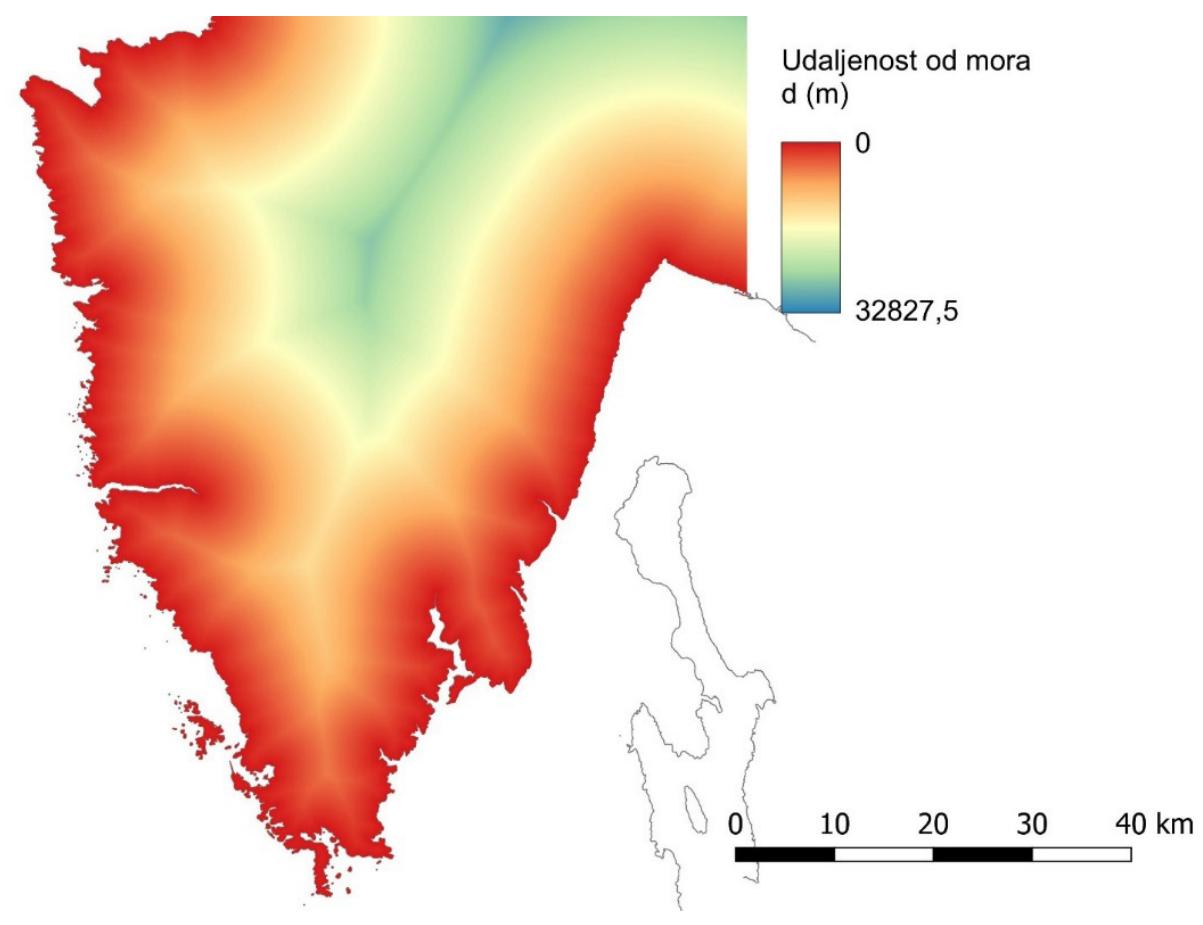

Slika 9. Udaljenost od mora

Uz poznati geografski položaj i nadmorsku visinu oborinskih postaja određena je njihova udaljenost od mora temeljem rastera udaljenosti od mora te je, uz poznatu količinu oborina, definiran višestruki regresijski model s količinama oborina kao zavisnom varijablom i četiri nezavisne varijable (3): geografska širina i dužina, nadmorska visina te udaljenost od mora.

$$
P=-42855,42+0,0111 \cdot X+0,0081 \cdot Y+0,6153 \cdot H-0,013 \cdot d
$$

gdje je:

$X$ : geografska dužina

$Y$ : geografska širina

$H$ : nadmorska visina

$d$ : udaljenost od mora

Tako dobiveni model primijenjen je na prostornoj domeni te je dobivena prostorna raspodjela oborina prikazana na Slici 10. 

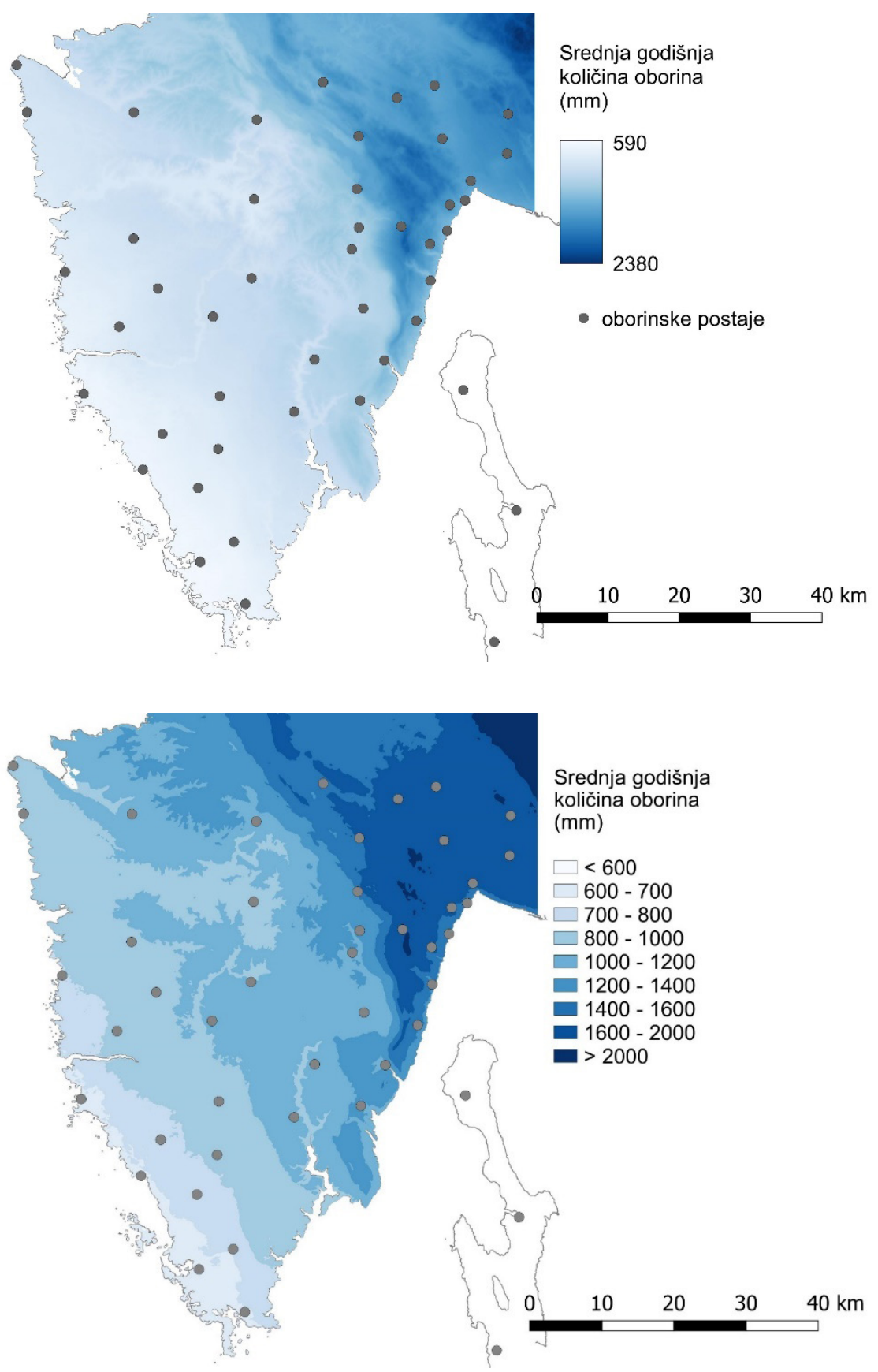

Slika 10. Prostorna interpolacija srednje godišnje količine oborina metodom višestruke regresije: a) kontinuirano polje količine oborina; b) klasificirana prostorna raspodjela oborina 
Budući da ova metoda u procjeni količine oborina u obzir uzima faktore koji utječu na promatrani fenomen (geografski položaj, nadmorska visina i udaljenost od mora), prostorna raspodjela se razlikuje od prethodne dvije - kontinuirana funkcija, kojom se određuje vrijednost količine u svakoj točki prostora (3), primijenjena je na cijelom području te nema diskontinuiranosti kao u prethodne dvije metode. Prethodno opisane nezavisne varijable omogućuju procjenu oborina ovisno o specifičnostima analiziranog područja, što pridonosi boljem uvidu u prostornu raspodjelu oborina. Međutim, kako je ovdje, za razliku od prethodno primijenjenih metoda, riječ o nepreciznoj metodi, na lokacijama oborinskih postaja procijenjene vrijednosti odstupaju od izmjerenih vrijednosti (Slika 11). Općenito, odstupanja su najveća na jugu i jugozapadu Istre, koje je ujedno i najsušniji dio područja, a smanjuju se prema unutrašnjosti poluotoka.

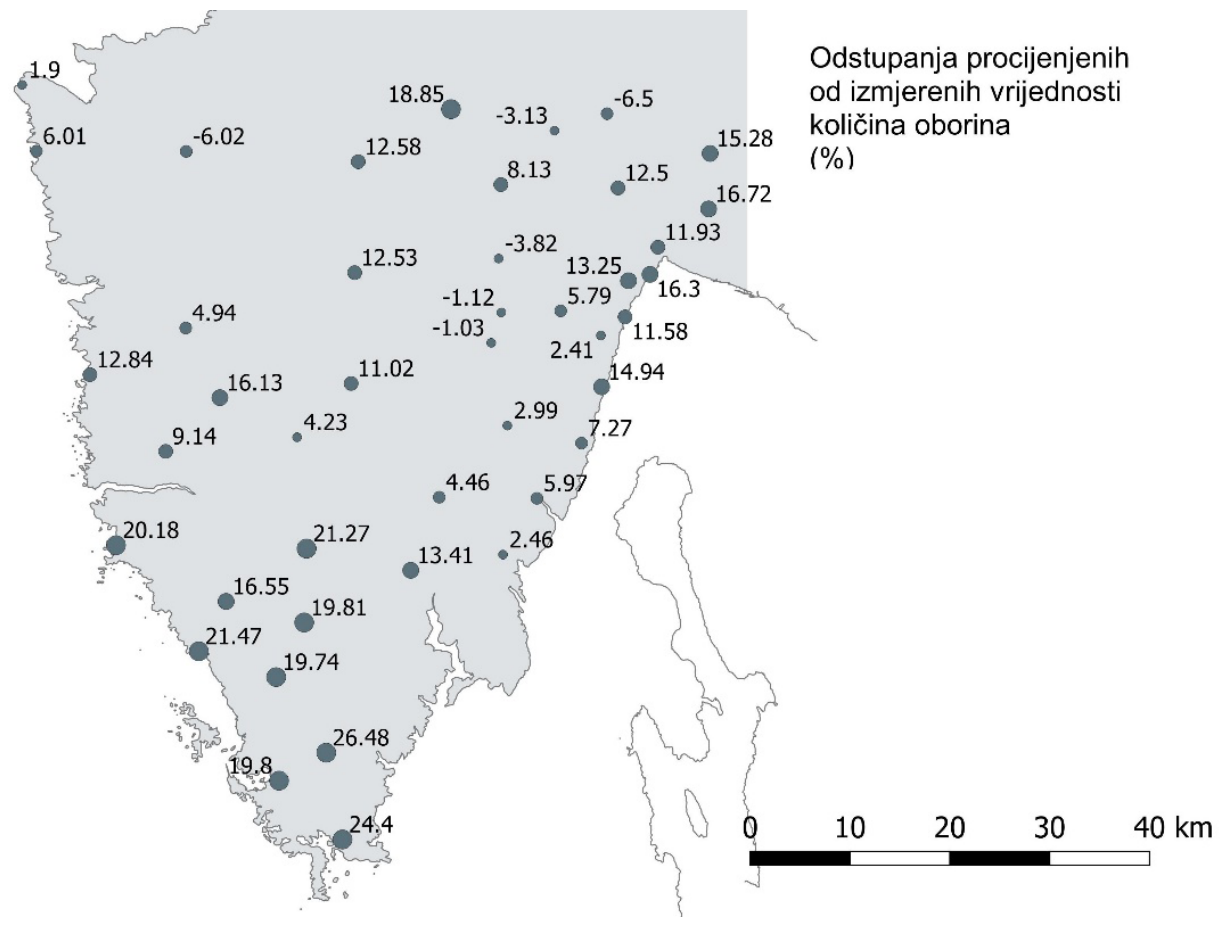

Slika 11. Odstupanja procijenjenih od izmjerenih vrijednosti količina oborina primjenom metode višestruke linearne regresije (negativan predznak označava procijenjenu oborinu veću od izmjerene) 


\section{Zaključak}

Od sve tri korištene metode prostorne interpolacije promatranog područja Istarskog poluotoka, višestruka linearna regresija pruža najrealnije rezultate $\mathrm{u}$ kontekstu opisa prostorne raspodjele količine oborina. Ujedno je i najkompleksnija i najkompliciranija radi obima ulaznih podataka te postupaka obrade podataka. Metoda Thiessenovih poligona i TIN metoda zahtijevaju samo količine oborina kao ulazne podatke, a algoritmi su već ugrađeni u GIS alate (u ovom radu korišten je QGIS softver), što uvelike olakšava i ubrzava postupak interpolacije. S druge strane, obje metode imaju i nedostatke u opisivanju prostorne raspodjele količina oborina, što su prvenstveno nemogućnost ekstrapolacije analiziranog procesa izvan područja omeđenog oborinskim postajama te neizglađenost površina (nagle promjene količine oborina u susjednim zonama kod metode Thiessenovih poligona i nagle promjene nagiba susjednih trokuta kod TIN metode). Odabir primjerene metode prostorne interpolacije, kao što je navedeno i u uvodu, najteža je odluka prilikom izrade prostorne raspodjele srednje godišnje količine oborina. Stoga je nužno u odabiru pažljivo analizirati brojne faktore, prvenstveno raspoloživost podataka, specifičnosti analiziranog fenomena i područje u kojem se provodi istraživanje te samu namjenu odnosno zahtijevanu razinu točnosti $\mathrm{i}$ preciznosti konačne karte prostorne raspodjele.

\section{Literatura}

[1] Gajić-Čapka, M.: Oborina na širem dubrovačkom području. Hrvatske vode, 18 (2010), 74, 305-312.

[2] Bonacci, O.: Oborine: glavna ulazna veličina u hidrološki ciklus. GEING, Split, 1994.

[3] Šiljeg, A.: Digitalni model reljefa u analizi geomorfometrijskih parametara - primjer PP Vransko jezero. Doktorska disertacija, Sveučilište u Zagrebu, Prirodoslovno-matematički fakultet, Geografski odsjek, Zagreb, 2013.

[4] Yang, X.: Spatial Interpolation. Handbook of Research on Geoinformatics (ur. Karimi, H. A.), Information Science Reference, Hershey - New York, 2009, 129-137.

[5] Mitas, L., Mitasova, H.: Spatial Interpolation. Geographical Information Systems: Principles, Techniques, Management and Applications ( $2^{\text {nd }}$ edition) (ur. Longley, P., Goodchild, M. F., Maguire, D. J., Rhind, D. W.), Wiley, Chichester, 2005, 481-492.

[6] Hrelja, H.: Inženjerska hidrologija. Građevinski fakultet Univerziteta u Sarajevu, Sarajevo, Bosna i Hercegovina, 2007.

[7] Mesić Kiš, I.: Odabir najprimjerenijeg kartiranja za prikaz ležišnih svojstava i geološke evolucije gornjomicenskih stijena u sjevernom dijelu Bjelovarske 
subdepresije. Seminarski rad, Sveučilište u Zagrebu, Prirodoslovnomatematički fakultet, Geološki odsjek, Zagreb, 2015.

[8] Brassel, K. E. i Reif, D.: A Procedure to Generate Thiessen Polygons. Geographical Analysis, 11 (1979), 3, 289-303.

[9] Weibel, R. i Heller, M.: Digital Terrain Modelling. Geographical Information Systems: Principles and Applications (ur. Maguire, D. J., Goodchild, M. F., Rhind, D.), vol. 1, Longman, Harlow, 1991, 269-297.

[10] Montgomery, D. C. i Runger, G. C.: Applied Statistics and Probability for Engineers. John Wiley \& Sons, 2010.

[11] Rubinić, J.: Vodni resursi i značajke kopnenih voda Istre u sušnim razdobljima - hidrološka studija. Knjiga 1 (nepublicirano). Sveučilište u Rijeci, Građevinski fakultet, Rijeka, 2005.

[12] DHMZ: Klimatski atlas Hrvatske. Državni hidrometeorološki zavod, Zagreb, 2008.

[13] DHMZ: Meteorološke postaje u Republici Hrvatskoj (http://meteo.hr/ infrastruktura.php?section=mreze_postaja\&param=pmm) (pristupljeno: 10.11.2020.)

[14] EEA: European Digital Elevation Model (EU-DEM, version 1.1. European Environment Agency, EU, 2015. 
